\title{
Fluoxetine Inhibits Calcium Influx in MIN6 cells
}

\author{
Ahmed S. Hisab, M.phil. \\ Medical School, University of Nottingham, Nottingham, UK
}

Doi: 10.19044/esj.2018.v14n27p10 URL:http://dx.doi.org/10.19044/esj.2018.v14n27p10

\begin{abstract}
Fluoxetine, a widely used antidepressant that primarily acts as a selective serotonin reuptake inhibitor, inhibits various membrane receptors and $\mathrm{Ca}^{2+}$ influx by unknown mechanism. In addition, it has been shown that $\mathrm{Ca}^{2+}$ is control mitochondrial metabolism and respiration. Here, effect of fluoxetine on the voltage gated Calcium channels in MIN6 cells was examined. Using $\mathrm{Ca}^{2+}$ imaging is to assess intracellular calcium. Fluoxetine $30 \mu \mathrm{M}$ inhibited $\mathrm{ca}^{2+}$ levels. These results indicated a tighter binding of fluoxetine to the Calcium than to the resting state of other channels, suggesting a more potent inhibition of $\mathrm{Ca}^{2+}$ channels at physiological resting membrane potential. Altogether, these data demonstrate that clinically relevant concentrations of fluoxetine exert a voltage-dependent block of channels that may contribute to this antidepressant's pharmacological effects.
\end{abstract}

Keywords: Fluoxetine, $\mathrm{Ca}^{2+}$ channels, mitochondria, insulin secretion, pancreatic $\beta$-cell.

\section{Introduction}

Fluoxetine is a psychoactive drug widely prescribed in many psychiatric disorders, including depression, obsessive-compulsive disorder and bulimia nervosa. The therapeutic action of fluoxetine primarily results from the inhibition of serotonin reuptake (Stark, Fuller et al. 1985, Wong, Bymaster et al. 1995), thus enhancing serotoninergic neurotransmission. Besides this mechanism, fluoxetine has several other modulatory effects, such as inhibition of G protein-coupled receptors (Stanton, Bolden-Watson et al. 1993, Pälvimäki, Roth et al. 1996), blockade of monoamine oxidases (Mukherjee and Yang 1999), and modulation of several ionic channels. Indeed, it has been reported that fluoxetine is a potent blocker of $\mathrm{K}$ channels (Thomas, Gut et al. 2002, Choi, Choi et al. 2003, Kobayashi, Washiyama et al. 2003, Kennard, Chumbley et al. 2005), $\mathrm{Na}^{+}$channels (Pancrazio, Kamatchi et al. 1998) and $\mathrm{Ca}^{2+}$ channels (Deák, Lasztóczi et al. 2000). T-type $\mathrm{Ca}^{2+}$ channels, a subgroup of voltage-gated $\mathrm{Ca}^{2+}$ channels, are the target of many 
antipsychotic drugs. For example, study by Deak et al. (2000) reporting that fluoxetine inhibits $\mathrm{T}$-type $\mathrm{Ca}^{2+}$ currents in rat hippocampal pyramidal cells.

The widely accepted key process of glucose stimulated insulin secretion from the beta cell upon glucose stimulation is ATP-sensitive $\mathrm{K}^{+}$ channel $\left(\mathrm{K}^{+}\right.$-ATP) dependent. In beta cells, the glut-2 transporter facilitates glucose entry. The glucose is then phosphorylated to glucose -6- phosphate by the enzyme glucokinase $(\mathrm{GK})$, which has a $\mathrm{Km}$ of approximately $5 \mathrm{mM}$ for glucose explains the concentration dependence of the $\beta$-cell response to glucose in the physiological range to stimulate insulin release (Matschinsky, Liang et al. 1993, Aguilar-Bryan and Bryan 1999). Pyruvate is formed from glucose, which is either transformed to lactate by anaerobic glycolysis or enters the mitochondria and is formed by tricycaboxylic acid (TCA) cycle to activate the respiratory chain in order to generate adenosine triphosphate (ATP). Increased ATP/ADP ratio causes closure of the $\mathrm{K}^{+}$-ATP sensitive channel, leading to a depolarization of cell membrane (Aguilar-Bryan and Bryan 1999), allowing the L- type $\mathrm{Ca}^{2+}$ channels in the cell membrane to open, causing an increase in cytosolic $\mathrm{Ca}^{2+}$. This promotes exocytosis of insulin secretory vesicles.

Therefore, it is of importance to characterize fluoxetine's action on the $\mathrm{Ca}^{2+}$ influx and their inhibition by fluoxetine should be investigated for a better understanding of this antidepressant's therapeutic action and side effects. In this article, it has been reported the first electrophysiological study of the inhibitory effects of fluoxetine on $\mathrm{Ca}^{2+}$ influx of MIN 6 pancreatic beta cells.

\section{Methodology Cell line}

The MIN6 (Mouse pancreatic beta ) cell line is a well-established, time honored, model for the study of pancreatic b-cell function (Miyazaki, Araki et al. 1990, Ishihara, Asano et al. 1993, Daunt, Dale et al. 2006, Cataldo, Cortés et al. 2015). The main advantage of a cell line for pancreatic b-cell research is that it large numbers of phenotypically homogenous cells are available which are devoid of paracrine and neuroendocrine effects that arise from interaction with the other endocrine and neuronal cell types that reside within the pancreatic islet (Ishihara, Asano et al. 1993). Although MIN6 have been reported to contain and secrete other pancreatic endocrine hormones, these cells still remain primarily b-cell in function (Nakashima, Kanda et al. 2009). Cells were grown, and the chronic experiments performed, in Dulbecco's modified Eagle's medium (DMEM) which contained $25 \mathrm{mM}$ glucose and was supplemented with: $2 \mathrm{mM}$ L glutamine, $10 \%$ fetal calf serum, $50 \mathrm{mM} 2-$ mercaptoethanol, and 25mM HEPES. In this study, cells from passage numbers 35-42 were used. 


\section{Intracellular $\mathrm{Ca}^{2+}$ measurements}

To enable imaging (Smith, Proks et al.)i of MIN6 cells, cells were loaded with the fluorescent $\mathrm{Ca}^{2+}$ indicator dye Fluo-4 AM (acetoxymethyl). Fluo-4 is an analog of Fluo-3 with the two chlorine substituents replaced by fluorines. Manufacturers report increased fluorescence excitation at $488 \mathrm{~nm}$ resulting in higher fluorescence signal levels (Invitrogen). Fluo-4 AM can be used at lower dye concentrations to generate the same fluorescence signal intensity (Gee, Brown et al. 2000). Lower loading concentrations and dye loading times of Fluo-4 AM make its use in cells a less invasive practice (Gee, Brown et al. 2000).

To monitor changes in the bulk intracellular $\mathrm{Ca}^{2+}$, we used the $\mathrm{Ca}^{2+}$ fluorophore Fluo-4, as previously descried (Duchen, Smith et al. 1993, Smith, Duchen et al. 1995). MIN6 cells, they were plated onto $22 \mathrm{~mm}$ glass coverslips. The cells were incubated with Fluo 4-AM (at a final concentration of $1 \mu \mathrm{M}$ in $0.1 \% \mathrm{BSA}(\mathrm{wt} / \mathrm{vol}), 10 \mathrm{mM}$ glucose, Hank's solution) for 20 minutes in the dark at room temperature $\left(21^{\circ} \mathrm{C}-22^{\circ} \mathrm{C}\right)$. Loading was performed at room temperature to decrease the likelihood of dye compartmentalisation in accordance with the manufacturer's recommendations (Invitrogen). The cells were washed by perifusion for 10 minutes in $\mathrm{Ca}^{2+}$-containing Hank's solution. To perifuse the microscope chamber, solutions were gravity-fed through polythene tubing. All drug additions were made via bath perifusion. Exchange between solutions was performed using an electrically controlled two-way valve.

The MIN6 cells were unresponsive to the $50 \mathrm{mM} \mathrm{K} \mathrm{K}^{+}$calibration procedure and $10 \mathrm{mM}$ glucose; or if the $\mathrm{Ca}^{2+}$ levels continuously decreased throughout the experiment, MIN6 cells that did not respond to extracellular $\mathrm{Ca}^{2+}$ removal were also excluded. Data were output as \% fluorescence, and expressed as mean \pm S.E.M. For each protocol presented at least 4 different MIN6 cell preparations were used and " $n$ " the number of MIN6 cells given as the sum total from these preparations.

\section{Results}

\section{Calcium channels are inhibited by fluoxetine in response to glucose}

The Previous results suggest that fluoxetine and low $\mathrm{Ca}^{2+}$ both inhibit mitochondrial function of MIN6 cells. The aim of these experiments was to assess the effect of fluoxetine on $\mathrm{Ca}^{2+}$ influx in presence of $10 \mathrm{mM}$ glucose. At basal glucose concentrations, $\mathrm{Ca}^{2+}$ transients were usually absent (Fig. 1A). Addition of $10 \mathrm{mM}$ glucose after a 1 minute delay caused transient fell and followed by a significant increase in intracellular $\mathrm{Ca}^{2+} \sim 11 \pm 0.83 \%$ ( $\mathrm{p}<$ 0.0001, Sidak's multiple comparisons test) compared to the basal ( Fig. 1A\&B). $30 \mu \mathrm{M}$ fluoxetine inhibited $\mathrm{Ca}^{2+}$ in the presence $10 \mathrm{mM}$ glucose by $\sim 9.4 \pm 2.7 \%$ ( $\mathrm{p}<0.05$, Sidak's multiple comparisons test) which partly 
recovered an washout ( $\mathrm{p}<0.0001$, Sidak's multiple comparisons test) (Fig. $1 \mathrm{~A} \& \mathrm{~B}$ ). Final addition of $50 \mathrm{mM} \mathrm{K}^{+}$(depolarization of cell membrane to -40 $\mathrm{mV}$ (Sharp 1996, Aguilar-Bryan and Bryan 1999) caused a rapid increase in $\mathrm{Ca}^{2+}$ levels (Fig. 1A). The experiment protocol was repeated but $50 \mathrm{mM} \mathrm{K}$ was replaced by perifusion of low $\mathrm{Ca}^{2+}$ which mimic the effect of fluoxetine (Fig. 2).
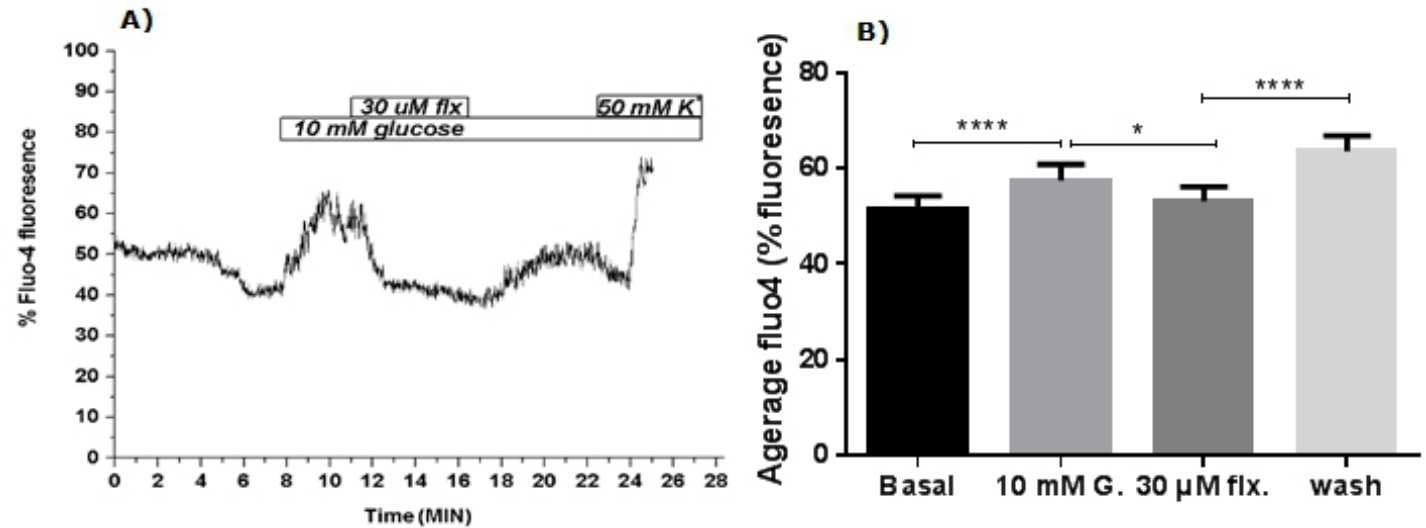

Fig. 1: Effect of $10 \mathrm{mM}$ glucose and $30 \mu \mathrm{M}$ fluoxetine on the $\mathrm{Ca}^{2+}$ response in MIN6 cells. A) Representative effect of $10 \mathrm{mM}$ glucose and $30 \mu \mathrm{M}$ fluoxetine on the $\mathrm{Ca}^{2+}$ influx of a single cell measured by the $\%$ change in fluoresence signal relative to $50 \mathrm{mM} \mathrm{K}$. B) Mean $( \pm$ SEM) response to the serial additions as indicated $10 \mathrm{mM}$ glucose (G.) and $30 \mu \mathrm{M}$ fluoxetine (flx). $\mathrm{N}=50$ cells collected from 3 experiments where the minimum number of cells is 3 in each one.

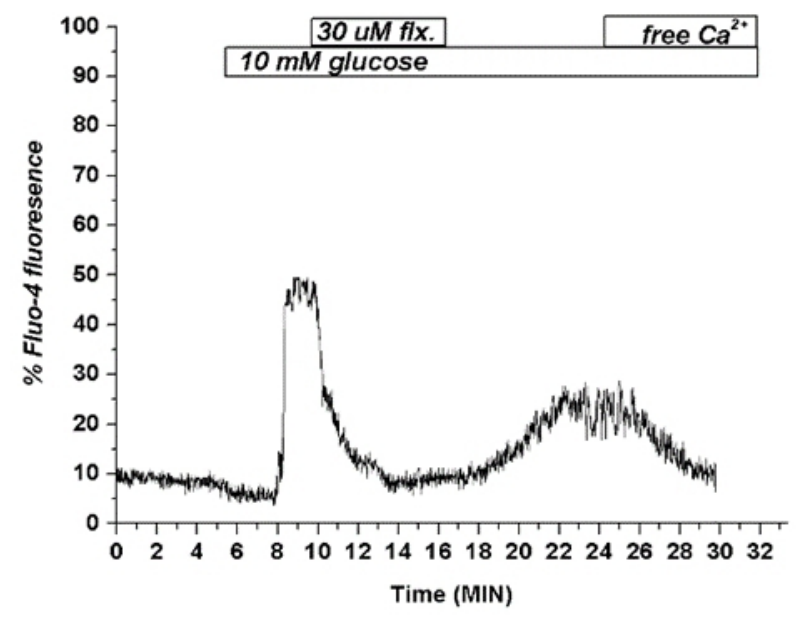

Figure 2: Representative effect of $10 \mathrm{mM}$ glucose and $30 \mu \mathrm{M}$ fluoxetine on the $\mathrm{Ca}^{2+}$ influx of a single cell. $\mathrm{N}=40$ cells collected from 3 experiments where the minimum number of cells is 3 in each one. 
To verify that fluoxetine inhibits voltage calcium channels. The effect of $30 \mu \mathrm{M}$ fluoxetine in response to $20 \mu \mathrm{M}$ tolbutamide ( $\mathrm{Tb}$ ) was explored. Since $\mathrm{Tb}$ blocks $\mathrm{K}^{+}$-ATP channel and increases $\mathrm{Ca}^{2+}$ influx and reveal any effect that may be seen regarding to direct block of $\mathrm{Ca}^{2+}$ voltage dependent channel by fluoxetine. Tolbutamide $(20 \mu \mathrm{M})$ stimulated $\mathrm{Ca}^{2+}$ signal by $\sim 15 \pm 1.48 \%(\mathrm{P}<$ 0.0001, Dunnett's multiple comparisons test) after a delay of 1 minute. Subsequent addition of $30 \mu \mathrm{M}$ fluoxetine abolished the $\mathrm{Ca}^{2+}$ influx in the presence of tolbutamide ( $\mathrm{P}<0.0001$, Dunnett's multiple comparisons test)(Fig. $3 A \& B)$. The vehicle for the fluoxetine, water, had no effect on the $\mathrm{Ca}^{2+}$ influx in the presence of tolbutamide (Fig. 3C\&D).
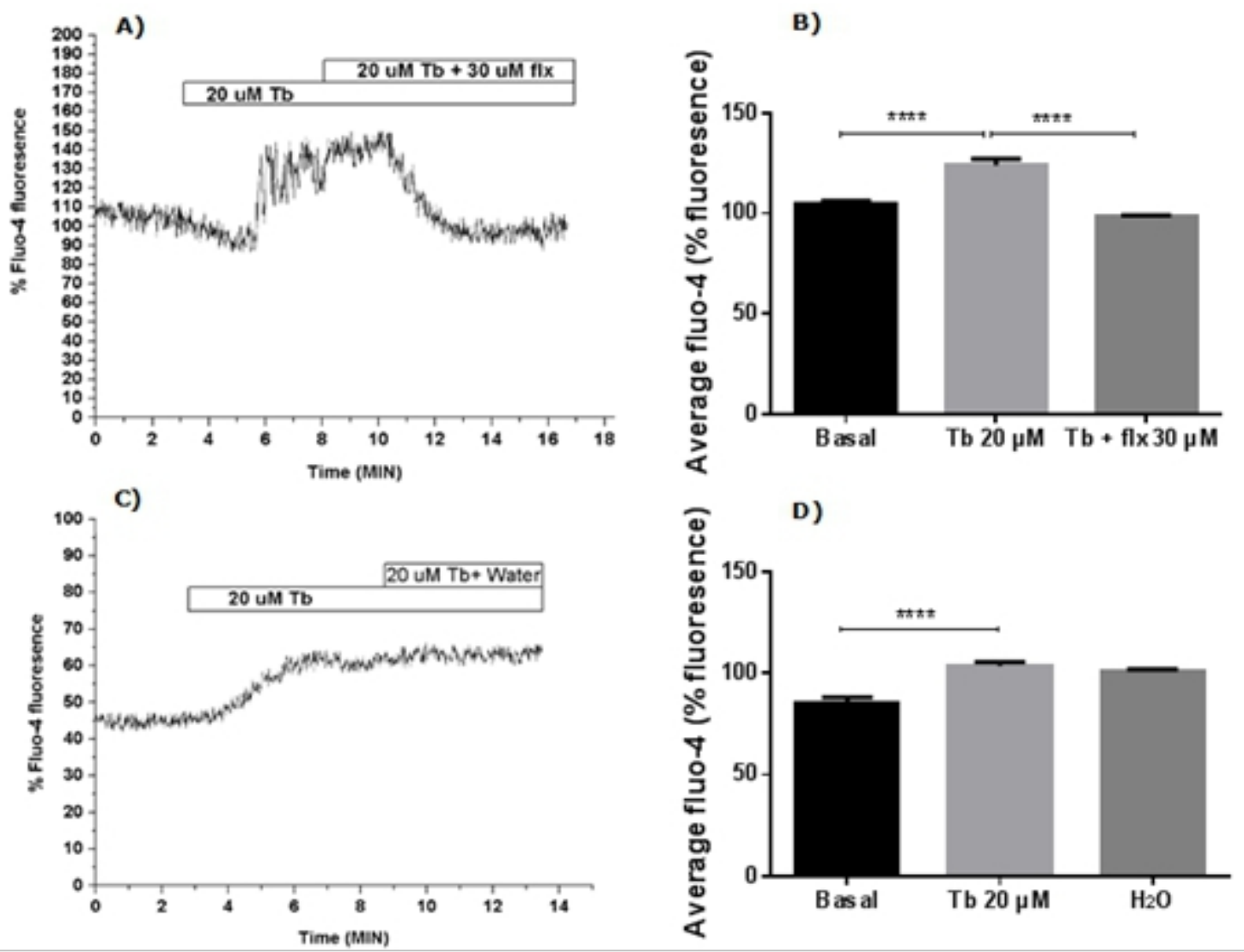

Fig. 3: Effect of $30 \mu \mathrm{M}$ fluoxetine on $\mathrm{Ca}^{2+}$ in presence of $20 \mu \mathrm{M}$ tolbutamide (Tb). A, C) Representative effect of $20 \mu \mathrm{M}$ Tolbutamide(Tb) and $30 \mu \mathrm{M}$ fluoxetine (flx) or water respectively on the $\mathrm{Ca}^{2+}$ influx of a single cell monitored by the change in Fluo-4 fluorescence. B, D) Mean $( \pm$ SEM) of single cells in response to the serial additions as indicated $20 \mu \mathrm{M}$ Tolbutamide and $30 \mu \mathrm{M}$ fluoxetine or $\mathrm{H}_{2} \mathrm{O}$ respectively. $\mathrm{N}=55$ cells collected from 5 experiments where the minimum number of cells is 3 in each one.

Figure 4. Shows that the percentage effect of $30 \mu \mathrm{M}$ fluoxetine in the presence of $20 \mu \mathrm{M}$ tolbutamide. The data showed that $30 \mu \mathrm{M}$ fluoxetine 
significantly decreased $\mathrm{Ca}^{2+}$ influx compared to the vehicle $\left(\mathrm{H}_{2} \mathrm{O}\right)(\mathrm{P}<0.0001$, Mann Whitney test).

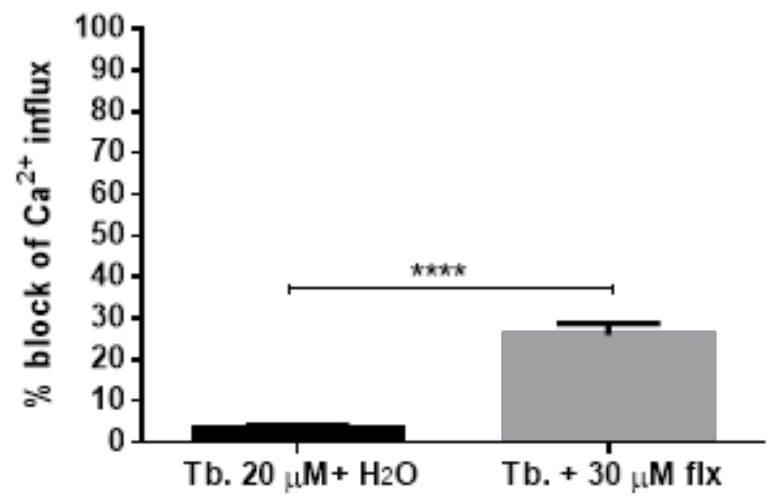

Fig. 4: The percentage block of $30 \mu \mathrm{M}$ fluoxetine in presence of tolbutamide (Tb) on the $\mathrm{Ca}^{2+}$ influx in MIN6 cells. Experimental data for this figure were sourced from figure 14B\&D. Values are shown as \% change in $\mathrm{Ca}^{2+}$ levels compared to the vehicle $\left(\mathrm{H}_{2} \mathrm{O}\right)$. Data are presented as Mean \pm SEM.

\section{Calcium co-regulates oxidative metabolism in pancreatic beta cells}

The ability of $\mathrm{Ca}^{2+}$ to control mitochondrial metabolism and respiration has been mainly attributed to the activation of $\mathrm{Ca}^{2+}$-regulated dehydrogenase (Denton 2009, Griffiths and Rutter 2009), which accelerates oxidative metabolism associated with the formation of the reduced NAD $(\mathrm{P}) \mathrm{H}$. The aim of this experiments was to investigate the effect of $\mathrm{Ca}^{2+}$ on the $\mathrm{NAD}(\mathrm{P}) \mathrm{H}$ levels. Fig. 5A shows that the effect of $10 \mathrm{mM}$ glucose and $\mathrm{Ca}^{2+}$ free on the $\mathrm{NAD}(\mathrm{P}) \mathrm{H}$ levels. Once NADPH levels reached steady-state after glucose stimulation ( $\mathrm{p}<0.0001$, Dunn's multiple comparisons test), subsequent addition of free $\mathrm{Ca}^{2+}$ decreased $\mathrm{NAD}(\mathrm{P}) \mathrm{H}$ levels in the presence of glucose $\left(\mathrm{p}<0.0001\right.$, Dunn's multiple comparisons test)(Fig. 5B). Re-addition of $\mathrm{Ca}^{2+}$ recovered the $\mathrm{NAD}(\mathrm{P}) \mathrm{H}$ levels to the control (glucose) levels $(\mathrm{p}<0.0001$, Dunn's multiple comparisons test)(Fig. 5A). In summary, these results suggest that low $\mathrm{Ca}^{2+}$ may inhibit mitochondrial respiration. 

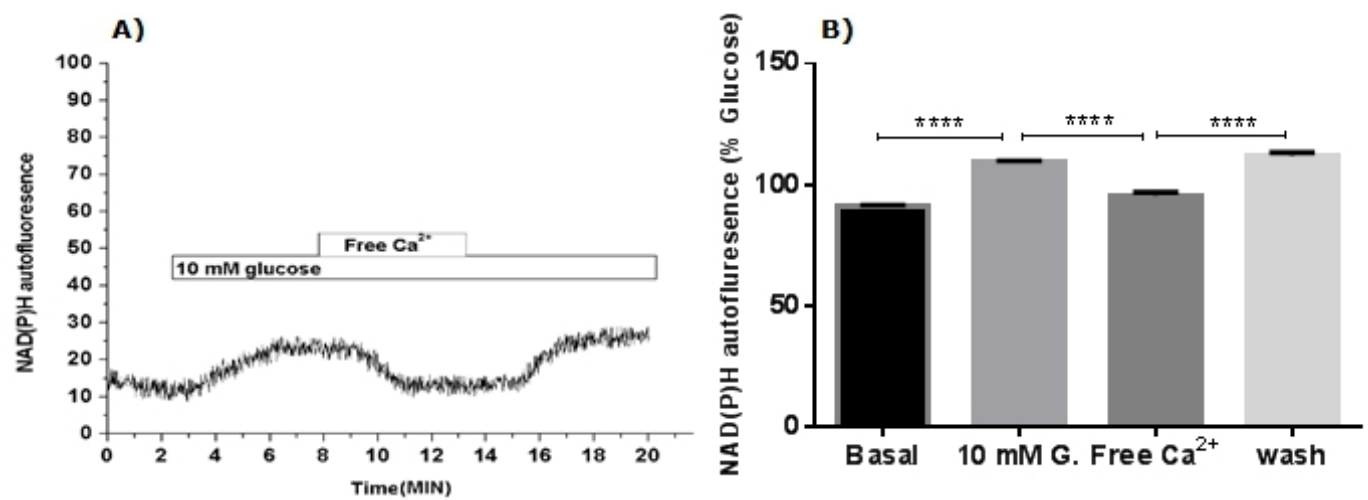

Fig. 5: Effect of calcium signalling on $\mathrm{NAD}(\mathrm{P}) \mathrm{H}$ responses in MIN6 cells. A) Representative effect of $10 \mathrm{mM}$ glucose (G.) and free $\mathrm{Ca}^{2+}$ on the NAD(P)H levels of a single cell. B) Mean $( \pm$ SEM) NADPH fluorescence for single cells in response to the serial additions as indicated. $\mathrm{N}=68$ cells collected from 4 experiments where the minimum number of cells is 15 in each one.

It has been shown that metabolism affects $\mathrm{Ca}^{2+}$ entry in MIN6 cells (Smith, Sellers et al. 2001, De Marchi, Thevenet et al. 2014). The aim of this experiment was to investigate the effect of rotenone on the $\mathrm{Ca}^{2+}$ influx. Within a minute of addition, $10 \mathrm{mM}$ glucose produced a large increase in the $\mathrm{Ca}^{2+}$ influx which is $\sim 17 \pm 1.27 \%$ ( $\mathrm{P}<0.0001$, Sidak's multiple comparisons test ) compared to the basal (Fig. 6A\&B). Subsequent addition of $1 \mu \mathrm{M}$ rotenone (complex I inhibitor) significantly inhibited $\mathrm{Ca}^{2+}$ signal by $\sim 18 \pm 2.47 \%(\mathrm{P}<$ 0.0001 , Sidak's multiple comparisons test ) in response to $10 \mathrm{mM}$ glucose (Fig. $6 \mathrm{~A} \& \mathrm{~B}$ ). Final addition of $50 \mathrm{mM} \mathrm{K} \mathrm{K}^{+}$(depolarization of cell membrane) considerably increased the $\mathrm{Ca}^{2+}$ signal (Fig. 6A).

A)

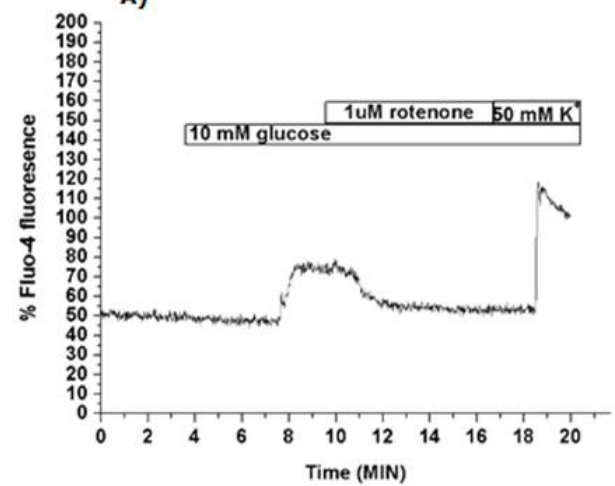

B)

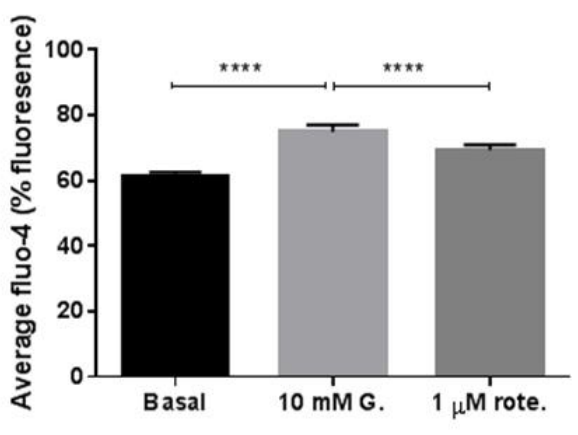

Fig. 6: Effect of $1 \mu \mathrm{M}$ rotenone on the $\mathrm{Ca}^{2+}$ in response to $10 \mathrm{mM}$ glucose. A) Representative effect of $1 \mu \mathrm{M}$ rotenone (rote) in the presence $10 \mathrm{mM}$ glucose on the $\mathrm{Ca}^{2+}$ influx of a single cell monitored by the \% change in Fluo-4 fluorescence relative to $50 \mathrm{mM}$ $\mathrm{K}^{+}(\% 100)$. B) Mean $( \pm \mathrm{SEM})$ of single cells in response to the serial additions as indicated 1 $\mu \mathrm{M}$ rotenone (rote) in the presence $10 \mathrm{mM}$ glucose (G.). $\mathrm{N}=76$ cells collected from 3 experiments where the minimum number of cells is 3 in each one. 


\section{Discussion}

\section{Effect of glucose and fluoxetine on $\mathrm{Ca}^{2+}$ influx}

Fluoxetine significantly inhibited $\mathrm{Ca}^{2+}$ influx by either a direct inhibition of $\mathrm{L}$ - type voltage dependent $\mathrm{Ca}^{2+}$ channels or an indirect impairment of mitochondria of pancreatic beta cells. In the present experiments, the $11 \%$ stimulation in the level of $\mathrm{Ca}^{2+}$ produced by $10 \mathrm{mM}$ glucose for MIN6 cells; these results are consistent with a central role for mitochondrial oxidative phosphorylation in coupling changes in glucose concentration with insulin release. For example, it has been found that, glucose-stimulated hyperpolarization of $\Delta \psi \mathrm{m}$ by increasing ATP/ADP ratio, leads to closure of $\mathrm{K}^{+}$-ATP channels, followed by depolarization cell membrane, leading to open L-Type Voltage $\mathrm{Ca}^{2+}$ channels and increased $\mathrm{Ca}^{2+}$ (Duchen, Smith et al. 1993, De Marchi, Thevenet et al. 2014). However, 30 $\mu \mathrm{M}$ fluoxetine significantly but reversibly inhibits $\mathrm{Ca}^{2+}$ levels. Isotonic replacement of $\mathrm{Na}^{+}$(by $50 \mathrm{mM} \mathrm{K}$ ) caused a rapid increase $\mathrm{Ca}^{2+}$ influx of these cells; an observation consistent with depolarization the cell membrane potential and activation of voltage-dependent $\mathrm{Ca}^{2+}$ channels (Duchen, Smith et al. 1993).

\section{Fluoxetine blocks $\mathrm{L}$ - type voltage dependent $\mathrm{Ca}^{2+}$ channels}

In present study, we found that $20 \mu \mathrm{M}$ tolbutamide increased $\mathrm{Ca}^{2+}$ influx; an observation consistent with previous finding which indicates that tolbutamide, stimulate insulin release from pancreatic $\beta$-cells predominantly by blocking the activity of ATP-sensitive $\mathrm{K}^{+}\left(\mathrm{K}^{+}\right.$-ATP $)$channels in the plasma membrane (Duchen, Smith et al. 1993, Smith, Proks et al. 1999). This causes membrane depolarization, activation of voltage-gated $\mathrm{Ca}^{2+}$ channels, increased $\mathrm{Ca}^{2+}$ influx, an increase in the cytosolic $\mathrm{Ca}^{2+}$ and insulin secretion.in the presence of tolbutamide. $30 \mu \mathrm{M}$ fluoxetine significantly decreased $\mathrm{Ca}^{2+}$. These data suggest that fluoxetine inhibits the L-type voltage dependent $\mathrm{Ca}^{2+}$ channel by direct mechanism in MIN6 cells. These results are comparable with The $\mathrm{IC}_{50}$ values obtained with fluoxetine for blocking of other ionic channels in different preparations. For example, the $\mathrm{IC}_{50}$ value of fluoxetine block of $\mathrm{T}$ type voltage calcium channels is $6.8 \mu \mathrm{M}$ and both $\mathrm{L}$ - and $\mathrm{N}$ - type voltage calcium channels is $3 \mu \mathrm{M}$ in rat hippocampal pyramidal cells (Deák, Lasztóczi et al. 2000) and (Pancrazio, Kamatchi et al. 1998) found that $20 \mu \mathrm{M}$ fluoxetine inhibited $\mathrm{N}$-type voltage $\mathrm{Ca}^{2+}$ channel in bovine adrenal chromaffin cells. (Traboulsie, Chemin et al. 2006) indicated that $30 \mu \mathrm{M}$ fluoxetine blocked Ttype voltage calcium channel in human embryonal kidney cells. To our knowledge, this is the first evidence for the inhibition of calcium channels by fluoxetine in MIN6 cell lines. 


\section{Fluoxetine inhibits $\mathrm{Ca}^{2+}$ entry by blocking metabolism}

In the present study, $10 \mathrm{mM}$ glucose increased level of $\mathrm{Ca}^{2+}$ influx in MIN6 cells. This can be accounted for by central role of mitochondrial oxidative phosphorylation in coupling changes in glucose concentration with insulin release (Duchen, Smith et al. 1993, De Marchi, Thevenet et al. 2014). It has been found that inhibition of respiration by inhibiting ATP synthesis with rotenone rapidly decreased intracellular $\mathrm{Ca}^{2+}$ in MIN6 cells. Our results underline the importance of continuous mitochondrial ATP synthesis to maintain beta cell $\mathrm{Ca}^{2+}$ signalling.

\section{Conclusion}

These data suggest that fluoxetine inhibited $\mathrm{Ca} 2+$ influx by two mechanisms: by direct block of voltage-dependent $\mathrm{Ca} 2+$ channels or by direct inhibition of mitochondrial function.

\section{References:}

1. Aguilar-Bryan, L. and J. Bryan (1999). "Molecular biology of adenosine triphosphate-sensitive potassium channels." Endocr Rev 20(2): 101-135.

2. Cataldo, L. R., et al. (2015). "Fluoxetine impairs insulin secretion without modifying extracellular serotonin levels in MIN6 $\beta$-cells." Exp Clin Endocrinol Diabetes 123(8): 473-478.

3. Choi, B. H., et al. (2003). "Fluoxetine blocks cloned neuronal A-type K+ channels Kv1.4." Neuroreport 14(18): 2451-2455.

4. Daunt, M., et al. (2006). "Somatostatin inhibits oxidative respiration in pancreatic beta-cells." Endocrinology 147(3): 1527-1535.

5. De Marchi, U., et al. (2014). "Calcium co-regulates oxidative metabolism and ATP synthase-dependent respiration in pancreatic beta cells." J Biol Chem 289(13): 9182-9194.

6. Denton, R. M. (2009). "Regulation of mitochondrial dehydrogenases by calcium ions." Biochim Biophys Acta 1787(11): 1309-1316.

7. Deák, F., et al. (2000). "Inhibition of voltage-gated calcium channels by fluoxetine in rat hippocampal pyramidal cells." Neuropharmacology 39(6): 1029-1036.

8. Duchen, M. R., et al. (1993). "Substrate-dependent changes in mitochondrial function, intracellular free calcium concentration and membrane channels in pancreatic beta-cells." Biochem J 294 ( Pt 1): 35-42.

9. Gee, K. R., et al. (2000). "Chemical and physiological characterization of fluo-4 $\mathrm{Ca}(2+)$-indicator dyes." Cell Calcium 27(2): 97-106. 
10. Griffiths, E. J. and G. A. Rutter (2009). "Mitochondrial calcium as a key regulator of mitochondrial ATP production in mammalian cells." Biochim Biophys Acta 1787(11): 1324-1333.

11. Ishihara, H., et al. (1993). "Pancreatic beta cell line MIN6 exhibits characteristics of glucose metabolism and glucose-stimulated insulin secretion similar to those of normal islets." Diabetologia 36(11): 11391145 .

12. Kennard, L. E., et al. (2005). "Inhibition of the human two-pore domain potassium channel, TREK-1, by fluoxetine and its metabolite norfluoxetine." Br J Pharmacol 144(6): 821-829.

13. Kobayashi, T., et al. (2003). "Inhibition of G protein-activated inwardly rectifying $\mathrm{K}+$ channels by fluoxetine (Prozac)." $\mathrm{Br} \mathrm{J}$ Pharmacol 138(6): 1119-1128.

14. Matschinsky, F., et al. (1993). "Glucokinase as pancreatic beta cell glucose sensor and diabetes gene." J Clin Invest 92(5): 2092-2098.

15. Miyazaki, J., et al. (1990). "Establishment of a pancreatic beta cell line that retains glucose-inducible insulin secretion: special reference to expression of glucose transporter isoforms." Endocrinology 127(1): 126-132.

16. Mukherjee, J. and Z. Y. Yang (1999). "Monoamine oxidase A inhibition by fluoxetine: an in vitro and in vivo study." Synapse 31(4): 285-289.

17. Nakashima, K., et al. (2009). "MIN6 is not a pure beta cell line but a mixed cell line with other pancreatic endocrine hormones." Endocr J 56(1): 45-53.

18. Pancrazio, J. J., et al. (1998). "Inhibition of neuronal $\mathrm{Na}+$ channels by antidepressant drugs." J Pharmacol Exp Ther 284(1): 208-214.

19. Pälvimäki, E. P., et al. (1996). "Interactions of selective serotonin reuptake inhibitors with the serotonin 5-HT2c receptor." Psychopharmacology (Berl) 126(3): 234-240.

20. Sharp, G. W. (1996). "Mechanisms of inhibition of insulin release." Am J Physiol 271(6 Pt 1): C1781-1799.

21. Smith, P. A., et al. (1995). "A fluorimetric and amperometric study of calcium and secretion in isolated mouse pancreatic beta-cells." Pflugers Arch 430(5): 808-818.

22. Smith, P. A., et al. (1999). "Direct effects of tolbutamide on mitochondrial function, intracellular $\mathrm{Ca} 2+$ and exocytosis in pancreatic beta-cells." Pflugers Arch 437(4): 577-588.

23. Smith, P. A., et al. (2001). "Somatostatin activates two types of inwardly rectifying $\mathrm{K}+$ channels in MIN-6 cells." J Physiol 532(Pt 1): 127-142. 
24. Stanton, T., et al. (1993). "Antagonism of the five cloned human muscarinic cholinergic receptors expressed in $\mathrm{CHO}-\mathrm{K} 1$ cells by antidepressants and antihistaminics." Biochem Pharmacol 45(11): 2352-2354.

25. Stark, P., et al. (1985). "The pharmacologic profile of fluoxetine." J Clin Psychiatry 46(3 Pt 2): 7-13.

26. Thomas, D., et al. (2002). "The antidepressant drug fluoxetine is an inhibitor of human ether-a-go-go-related gene (HERG) potassium channels." J Pharmacol Exp Ther 300(2): 543-548.

27. Traboulsie, A., et al. (2006). "T-type calcium channels are inhibited by fluoxetine and its metabolite norfluoxetine." Mol Pharmacol 69(6): 1963-1968.

28. Wong, D. T., et al. (1995). "Prozac (fluoxetine, Lilly 110140), the first selective serotonin uptake inhibitor and an antidepressant drug: twenty years since its first publication." Life Sci 57(5): 411-441. 